(Received June 30, 1982)

\title{
FATIGUE PHENOMENA OF SINGLE PULP FIBERS UNDER REPEATED TORSIONAL STRESS
}

\author{
By Tsutomu Naito *, Makoto Usuda and Takashi Kadoya \\ (Department of Forest Products, Faculty of Agriculture, \\ The University of Tokyo, Yayoi, Bunkyo-ku, Tokyo, Japan)
}

\section{Synopsis}

Fatigue life of soft wood pulp fibers has been measured using torsion pendulum method. The fatigue life of wet pulp fibers decreases with an increase in torque and axial load. At the same stress level, the fatigue life of kraft fibers was greater than that of sulfite fibers. Drying and dry-wet cycles reduce the fatigue life of fibers.

The difference in the fatigue phenomena between never-dried fibers and the fibers subjected to drying or dry-wet cycles, and the difference between kraft and sulfite fibers are interpreted on the basis of irreversible changes in the cell wall structure and the formation of defects.

\section{INTRODUCTION}

Many researchers have studied tensile properties of single pulp fibers, since the significance of the mechanical properties of paper-making fibers has been well recognized from scientific and practical standpoints. Page et al." have found that the tensile strength of dry single fibers with no obvious defects is controlled by the fibril angle regardless of wood species and fiber types, and it fits Hill's criterion of fracture for orthotropic materials. They have also suggested that the defects such as pits, wrinkles, node and dislocations, which initiate failure, decrease the fiber strength. In order to understand more precisely the fracture mechanisms of pulp fibers, fracture mechanics in stochastic process should be applied to the analysis.

The fatigue phenomena of pulp and paper are of importance in many practical situations involying beating of pulp, recycling and repeated folding of paper, however the investigation on this problem has scarcely been reported. A possible reason for this is the lack of adequate information for fatigue phenomena of single pulp fibers.

The present work deals with the fatigue phenomena of single pulp fibers using the torsion pendulum method.

* Present address: Central Research Laboratory, Jujo Paper Co., Ltd. (5-21-1, Oji, Kita-ku, Tokyo, Japan)

\section{EXPERIMENTAL}

\subsection{Pulp preparation}

Unbleached kraft pulp of 47 per cent yield was prepared from handmade chips of latewood of Akamatsu ( $P$. densiflora). The pulp was delignified by the sodium chlorite-acetic acid method at room temperature and defibered by gentle agitation. Sulfite pulp was also prepared from the Akamatsu latewood for comparison.

\subsection{Apparatus and Procedure}

The torsion pendulum systems used were described in a previous paper ${ }^{2)}$. In the present work, the apparatus was controlled automatically by a micro processor so that the sample fiber was twisted repeatedly under a constant torque. The free damping oscillations were recorded at regular time intervals until the fiber breakage.

Relative torsional rigidity and logarithmic decrement were calculated from the free damping oscillation curve. Fatigue life was defined as the number of cycles at which the fiber was broken.

The fatigue tests were carried out in wet state with about 50 fibers under stress levels in combination of three levels of torque $(3,6,10 \mathrm{nNm})$ and three levels of axial load $(1,3,5 \mathrm{~g})$.

Since the history of drying of pulp has a remarkable effect on the lamellae structure of the fiber, the kraft fibers were tested with the following programs: 
(1) The never-dried fibers were tested without any drying at $20^{\circ} \mathrm{C}$. (2) After 10 cycles of drying and rewetting at $20^{\circ} \mathrm{C}$, the fibers were tested in wet state. (3) After 10 cycles of drying at $80^{\circ} \mathrm{C}$ and rewetting at $20^{\circ} \mathrm{C}$, the fibers were tested in wet state. For comparison, dried fibers were tested at $20^{\circ} \mathrm{C}$ and $65 \% \mathrm{RH}$.

\section{RESULTS AND DISCUSSION}

\subsection{Variation of the torsional properties under repeated torsional stress}

Figure 1 shows variation of the torsional rigidity and logarithmic decrement with the number of cycles for a dry pulp fiber. The fiber was free from optically obvious defects. The torsional rigidity

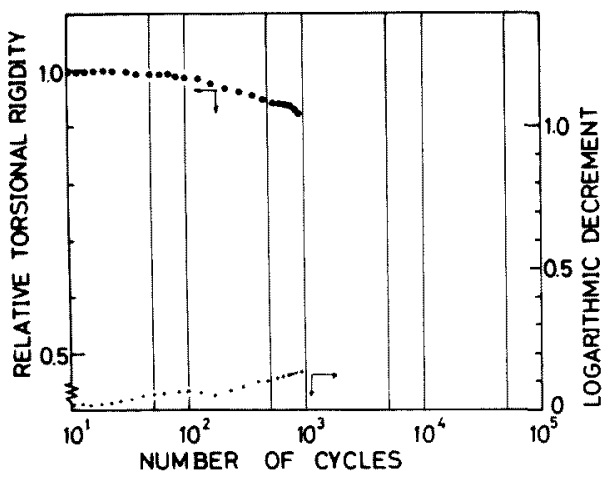

Fig. 1 Variation of torsional rigidity and logarithmic decrement with the number of cycles for a dry fiber of Akamatsu kraft pulp.

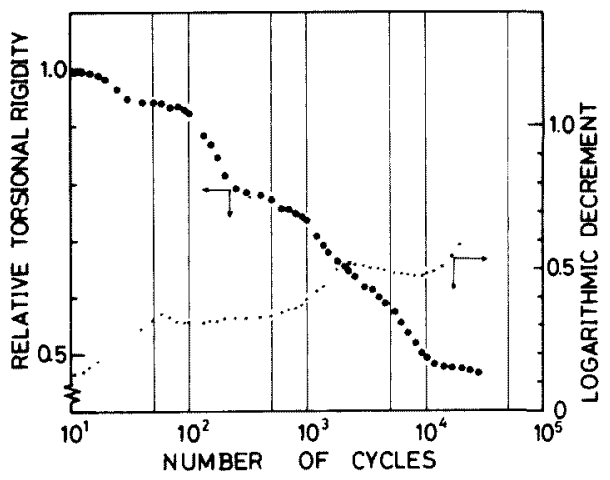

Fig. 2 Variation of torsional rigidity and logarithmic decrement with the number of cycles for a wet fiber of Akamatsu kraft pulp. decreases slightly with an increase in the number of cycles, while the decrement increases. Figure 2 shows variation of the rigidity and decrement with the number of cycles for a never-dried fiber from the same pulp. The torsional rigidity decreases stepwise with an increase in the number of cycles, and the fatigue failure occurs at about 50 per cent of the initial rigidity. It is also seen that the decrement exhibits several peaks in the fatigue process and a considerable increase before the breakage. The water within small interstices of a cell wall may absorb a part of a given energy, and delamination of the cell wall caused by swelling leads to dispersion of internal stress. Therefore, microcracks propagate gradually through the cell wall and further delamination may occur successively. In view of this, it seems likely that the decrease in the rigidity and the peaks of decrement reflect the changes in internal structure of wet fibers. On the other hand, dry fibers have smaller fatigue life than wet fibers, this may be the results of stress concentration inherent in defects and of the low damping.

\subsection{Fatigue lives of single pulp fibers}

Fatigue phenomena of materials such as glass and metal have been generally regarded as a stochastic process.

In the present work, the fracture mechanics in stochastic process proposed by Yokobori ${ }^{3)}$ was applied to the frequency distribution of fatigue lives of single pulp fibers.

\section{Theory}

If a fiber has probability of breakage $m$ at each cycle of a fatigue test, the probability of breakage at a cycle after $N$ th cycle is

$$
q(N)=Z_{N} / k
$$

and the probability of breakage after $N$ th cycle (the "frequency of survival") is

$$
\begin{aligned}
& P(N)=\sum_{n=N}^{\infty} Z_{n} / k \\
& P(N)=\int_{N}^{\infty} q(N) \mathrm{d} N
\end{aligned}
$$

where $Z_{n}$ is the number of broken fibers at $n$th cycle and $k$ is the number of tested fibers.

Assuming $N \gg 1$, we can regarded $N$ as a continuous variable.

Hence 


$$
\frac{\mathrm{d} P(N)}{\mathrm{d} N}=-q(N)=-m P(N)
$$

Integration of Eq. (4) leads to the result,

$$
\ln P=-m N, \text { or } \log _{10} P=-0.4343 m N
$$

because $P=1$ at $N=0$.

The frequency of survival $P$ is obtained from the histogram of fatigue life.

If a plot of $\log P$ against $N$ gives a straight line, the slope provides the constant, $-0.4343 \mathrm{~m}$. That is, a linear relationship between $\log P$ and $N$ implies that each tested fiber is broken, with a constant probability, by a twisting at each cycle.

Furthermore, the mean fatigue life $\bar{N}$ is given by Eq. (6), provided the probability $m$ is constant.

$$
\vec{N}=\int_{0}^{\infty} N \cdot q \mathrm{~d} N=\int_{0}^{\infty} \cdot N \cdot m \exp (-m N) \mathrm{d} N=1 / m
$$

and the variance $\sigma^{2}$ is given by Eq. (7).

$$
\begin{aligned}
\sigma^{2} & =\int_{0}^{\infty}(N-\bar{N})^{2} q \mathrm{~d} N \\
& =\int_{0}^{\infty}\left(N-\frac{1}{m}\right)^{2} m \exp (-m N) \mathrm{d} N=1 / m^{2}
\end{aligned}
$$

Consequently, the coefficient of variation $\sigma / \bar{N}$ is always 100 per cent. In present work, the coefficient of variation obtained varied from 95 to 120 per cent.

\section{Application}

Figure 3 illustrates the plot of $\log P$ vs. $N$ for wet fibers of Akamatsu latewood kraft pulp. The fibers were tested under three different levels of axial load and a constant torque. An approximately linear relationship exists between $\log P$ and $N$ after the latent cycles of survival. Therefore, the probability of breakage at each twist cycle is almost constant. The fact suggests that microcracks within a fiber wall propagate with a constant probability during the fatigue test. These structural changes in the wall may be reflected on the variation of the decrement with the number of cycles which has been shown in Fig. 2 .

It is also seen that an increase in axial load makes the slope of plot of $\log P$ vs, $N$ steep. The findings suggest that the mean fatigue life decreases with an increase in axial load as a result of an increase in the probability of breakage $m$. Similar findings are observed with the fatigue tests under different levels of torque and a constant axial load (Fig. 4). It is seen that the mean fatigue life

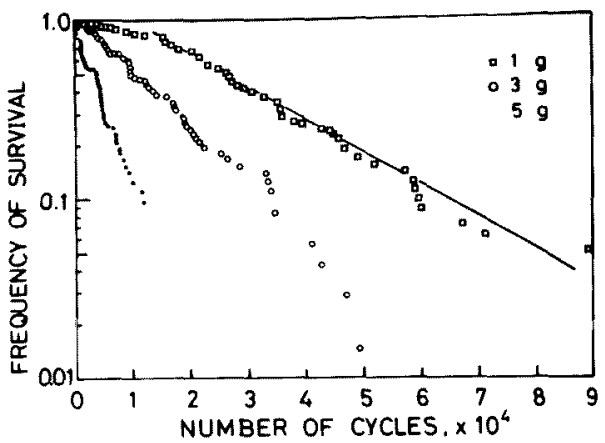

Fig. 3 Influence of applied load on fatigue life of Akamatsu latewood kraft fibers in waterswollen state. Applied torque: $3 \mathrm{nNm}$.

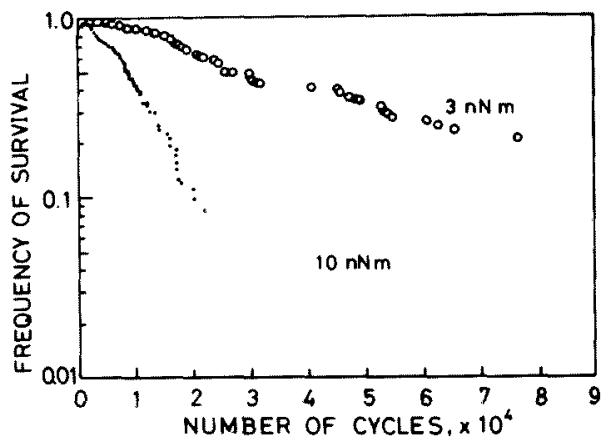

Fig. 4 Influence of applied torque on fatigue life of Akamatsu latewood kraft fibers in waterswollen state. Applied load: $1 \mathrm{~g}$.

decreases with an increase in torque.

The plot of $\log P$ vs. $N$ for dry fibers of the same pulp is given in Fig. 5, which shows that the mean fatigue life decreases with an increase in torque.

It is also seen from Fig. 4 and Fig. 5 that the fatigue life of dry fibers are smaller than that of wet fibers and relationship between $\log P$ and $N$ for dry fibers is nonlinear in comparison with that for wet fibers.

The latter finding suggests that the probability of breakage with each cycle is not always constant for all the dry fibers. These may be the results of stress concentration to the inherent defects within a fiber and of its low damping. On the other hand, it seems likely that the fatigue of wet fibers proceeds gradually, as the results of the absorption of the given energy by water and of the dispersion 


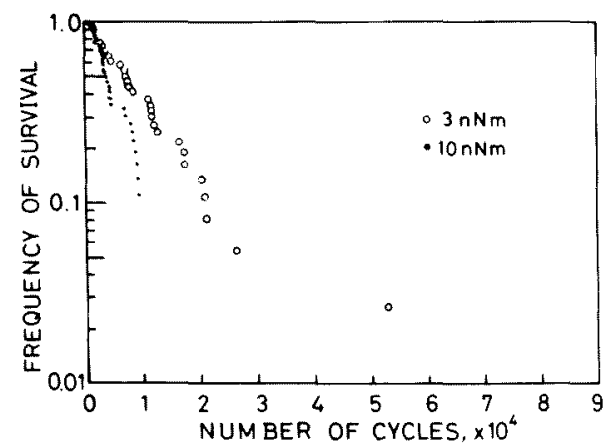

Fig. 5 Influence of applied torque on fatigue life of Akamatsu latewood kraft fibers in dry state.

of the given stress by swelling of cell wall.

Figure 6 and 7 show fatigue life as the functions of torque and axial load for kraft and sulfite fibers, respectively. It is seen that, at the same stress level, the fatigue life of kraft fibers is higher than that of sulfite fibers. The fatigue life of pulp fibers decreases with an increase in stress level. This finding is more clearly observed with sulfite fibers than kraft fibers. These differences may be attributed to a difference in the cohesive force within a cell wall on the basis of the fact that sulfite fibers have a greater degree of swelling than kraft fibers.

Figure 8 shows the variation of the torsional rigidity and logarithmic decrement with dry-wet cycles at $20^{\circ} \mathrm{C}$ for a never-dried fiber. It is seen that the initial rigidity of the never-dried fiber increases with the first two cycles and then decreases as the dry-wet cycle is repeated. The decrement has its minimum at about 6th cycle, and then it increases again. These findings are more clearly observed with the results obtained under the cycles of drying at $80^{\circ} \mathrm{C}$ and rewetting as shown in Fig. 9. Since the fibers were tested under a stress level which had no appreciable effect on their fatigue lives, these changes result only from the dry-wet cycle treatment. Jayme and Hunger ${ }^{4}$ suggested in their study on the hornification of pulp fibers that drying of a fiber turns the fibrils into larger unit and thereby a stiffer structure of the fiber is formed. Page and DeGrace $^{5)}$ have also shown the irreversible change in the structure of cell wall after drying. This

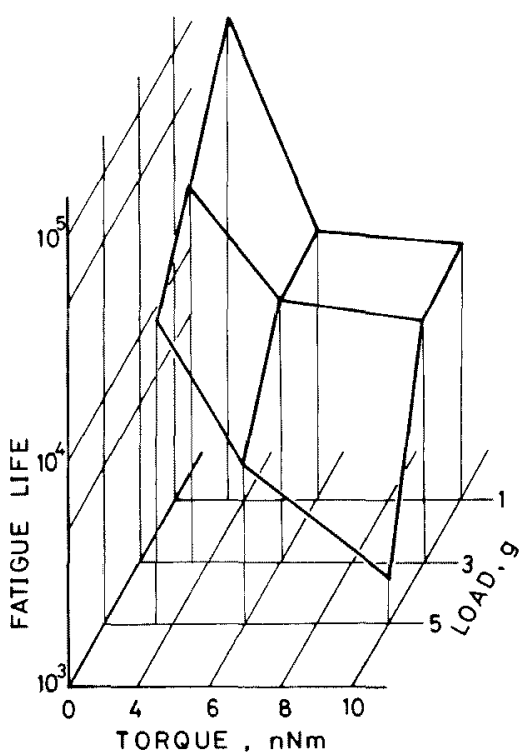

Fig. 6 Mean fatigue life of wet fibers of Akamatsu kraft pulp ( $51.5 \%$ yield).



Fig. 7 Mean fatigue life of wet fibers of Akamatsu sulfite pulp ( $51.9 \%$ yield).

suggestion was confirmed by measurement of the fiber saturation point (total pore volume) and specific surface area of pulp fibers by means of the solute exclusion method ${ }^{6)}$ as a function of 


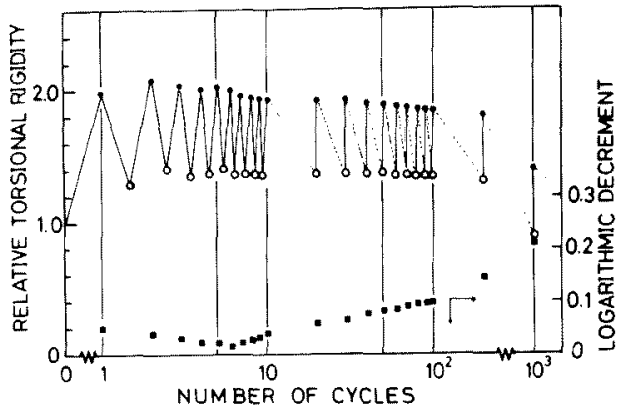

Fig. 8 Variation of torsional rigidity and logarithmic decrement with dry-wet cycles (at $20^{\circ} \mathrm{C}$ ) for a latewood kraft fiber.

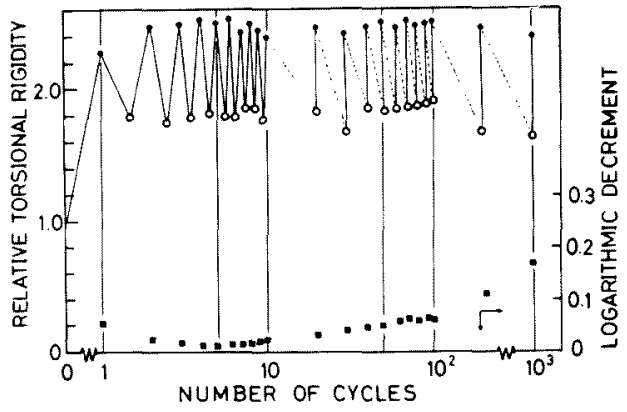

Fig. 9 Variation of torsional rigidity and logarithmic decrement with dry (at $80^{\circ} \mathrm{C}$ )-wet (at $20^{\circ} \mathrm{C}$ ) cycles for a latewood kraft fiber.

the number of dry-wet cycles (Fig, 10). The fiber saturation point and specific surface area decrease with dry-wet cycles. This finding implies that the dry-wet cycle leads to the irreversible cohesion of structural units.

The structural changes in cell wall with dry-wet cycles can be interpreted in terms of the fatigue phenomena of fibers. Figure 11 shows the plot of $\log P$ vs. $N$ for wet fibers tested after 10 dry-wet cycles at $20^{\circ} \mathrm{C}$, those tested after 10 dry (at $80^{\circ} \mathrm{C}$ )wet cycles and untreated wet fibers. It is clear that the dry-wet cycles make the slope steep, that is, they reduce fatigue lives of fibers. In addition to this, relation between $\log P$ and $N$ for the treated fibers is non linear in comparison with untreated fibers. The finding implies that the probability of breakage at each twisting cycle is not constant for all the treated fibers. This suggests that the dry-wet cycle causes the crack nucleus which leads to the stress concentration. It should



Fig. 10 Variation of fiber saturation point and specific surface area with dry-wet cycles. Key: $O, \triangle=$ at $20^{\circ} \mathrm{C} ; \bullet, \Delta=$ drying at $80^{\circ} \mathrm{C}$ and rewetting at $20^{\circ} \mathrm{C}$.

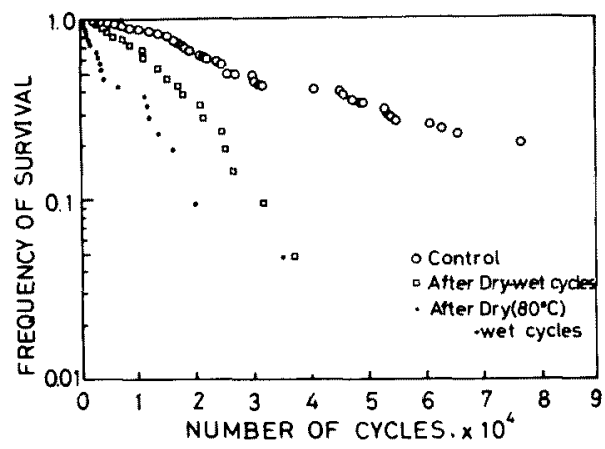

Fig. 11 Influence of dry-wet cycles on fatigue life of wet fibers of Akamatsu latewood kraft pulp.

be noted that this effect is more obviously found with the fibers which were subjected to the cycles of drying at $80^{\circ} \mathrm{C}$ and rewetting.

\section{CONCLUSION}

The fatigue life of $\mathrm{kraft}$ and sulfite fibers in water-swollen state decreased with increasing torque and axial load applied to the fibers. Under the same stress level, the fatigue life of kraft fibers was greater than that of sulfite fibers.

A linear relationship existed between the logarithm of frequency of survival $(\log P)$ and fatigue life $(N)$ for wet fibers. This finding suggested that micro-cracks were formed within a fiber wall and propagated with a constant probability during fatigue test. On the other hand, a decrease of the fatigue life with drying may result from the stress 
concentration to the defects caused by drying, because the relationship between $\log P$ and $N$ for the fibers subjected to dry-wet cycles is nonlinear in comparison with the untreated fibers. It was, therefore, suggested that the dry-wet cycle led to irreversible changes in the wall structure, and the formation of defects.

\section{REFERENCES}

1) D. H. Page, F. El-Hosseiny, K. Winkler and R. Bain, Pulp and Paper Mag. Can., 73 (8),
T198(1972)

2) T. Naito, M. Usuda and T. Kadoya, Tappi, 63 (7), $115(1980$

3) T. Yokobori, J. Phys. Soc. Japan, 8, 265 (1953)

4) G. Jayme and G. Hunger, "Fundamentals of Papermaking Fibers," (F. Bolam, ed), Technical Section BPBMA., London, 1958, p 263

5) D. H. Page and J. H. DeGrace, Tappi, 50 (10), 489 (1967)

6) J. E. Stone and A. M. Scallan, Tappi, $50(10)$, 496 (1967)

\section{繰り返し抚り応力下における製紙用単繊維の疲労現象}

東京大学䕕学部内藤勉，臼田誠人，門屋 卓

㹉り振子法を用いて，製縚用パルプ単繊維の疲労現象

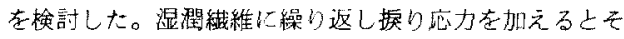
の回数に応して据り诚さは段階的に減少し，対数减衰率 はいくつかのピークをとりながら増加し破壊真前に著し い增加を示すことを認矿。一方乾燥織維では繰り返し 据り応力による揬り風さや減衰率の湾化はわずかであっ た。このような現象を解析寸るため材料の疲学に関寸る 確率過程的な取段い学入し考察を行なった結果，湿潤 織維では1回の繰り返し応力に対する破断の確率は一定

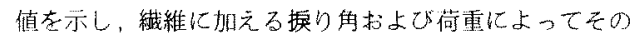

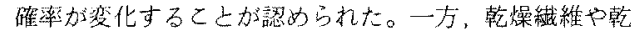
湿燥り返し㚾理をした瀻維では破断り確棌は一定でなく

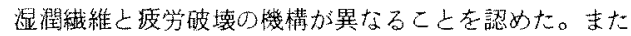
クラフトパルプと玶硫酸パルプの纖維を比較する上前者 は高い疲労寿命があり，据り㐫力や荷重老增加させると 媛者の疲労寿命が著しく低下した。以上の結果上り，乾 燥姏理やパルプ化法の違いが䋐維の潜在的欠陥しして披 学機構に影響を与えるもの上考繁した。 